\title{
Enforcing Judgments in Russian Economic Courts
}

\author{
Kathryn Hendley ${ }^{1}$
}

\begin{abstract}
An expert on Russian law and politics uses data drawn from interviews with participants in non-payment cases heard by arbitrazh courts in Moscow, Saratov, and Yekaterinburg in 2000, after efforts made in the late 1990s to reform the enforcement system of the courts. The data are used to identify the strategies creditors use to collect payments awarded to them, the outcomes of such efforts, and managers' attitudes toward arbitrazh courts. Regional differences in creditors' ability to enforce these judgments, as well as patterns in debtor behavior and creditors' use of arbitrazh courts, are identified and analyzed.
\end{abstract}

I

s going to court a waste of time for Russian firms? Most business litigation in Russia, as elsewhere, revolves around unpaid debt. When customers fail to pay for goods or services in a timely fashion, creditors can pursue legal remedies. Both the caseload statistics collected by the courts ${ }^{2}$ and enterprise-based surveys ${ }^{3}$ indicate that Russian firms are turning to the courts in ever-increasing numbers for assistance with debt collection. At the same time, my research has confirmed that, much like their coun-

\footnotetext{
${ }^{1}$ Professor of Political Science and Law, University of Wisconsin-Madison. Thanks are due to Timofey Mylovanov who ably assisted with the preparation of the tables, and to Michael Morgalla who provided research assistance. The field research would not have been possible without the cooperation and assistance of the Solidarity Center in Moscow, Sutyazhnik in Yekaterinburg, and the Center for Legal Reform in Saratov. Many people in these centers deserve thanks, including Irene Stevenson, Yelena Gerasimova, Yekaterina Sukhachyova, Sergey Belyayev, Svetlana Mukhambetova, Marina Nemytina, and Alexey Telovalnikov. Funding for the field research was provided by the National Council for Eurasian and East European Research. Funding while writing the article was provided by the Woodrow Wilson International Center for Scholars and the Law School at the University of WisconsinMadison.

${ }^{2}$ During the 1990s, the number of debt-related cases decided increased by about 160 percent (see Table 1). See Hendley and Murrell (2002) for more information on trends in the use of courts by Russian firms.
} 
terparts elsewhere, Russian managers view litigation as a last-ditch solution. Before filing a claim, they make every effort to convince their customers to pay voluntarily. Typically these efforts start with friendly phone reminders and ratchet up to letters and visits that threaten legal action (e.g., Hendley, 2001). No doubt some creditors cross the line into threats of physical violence and even follow through on them. ${ }^{4}$ When these informal mechanisms fail to yield payment, litigation becomes a possibility. In Russia, as elsewhere, the decision as to whether to pursue legal remedies requires a cost-benefit analysis. Managers have to weigh both the tangible and the intangible costs associated with litigation against the likelihood of prevailing and of collecting the judgment. Creditors are unlikely to be concerned or satisfied with moral victory; they want their money back.

Russian managers are undeniably frustrated by the difficulty of enforcing judgments. Economic disputes involving legal entities are heard by the arbitrazh courts (which are institutionally distinct from the courts of general jurisdiction, which resolve criminal and civil disputes involving individuals). In a 1997 survey of 328 industrial enterprises, we asked the heads of legal departments to assess a set of possible obstacles to using the arbitrazh courts, including financial expenses, delays, loss of privacy, judicial incompetence and bias, and enforcement (Hendley, Murrell, and Ryterman, 2000). These lawyer-managers were asked to evaluate these problems on a scale from 0 to 10 . Concern over the enforceability of judgments emerged as the single most pressing, with a mean score of 7.3, compared with mean scores of 5 and 3.6 for delays and judicial competence, respectively. Arbitrazh court insiders agree. From the chairman of the Higher Arbitrazh Court (Yakovlev and Yukov, 1999) to trial-level arbitrazh judges, enforcement is recognized as the Achilles' heel of the arbitrazh system (e.g., Vasil'yeva, 1998, 1996; Katanyan, in Nezavisimaya gazeta, January 16, 1997; Tarasovaya, in Stavropol'skaya pravda, January 23, 1997). The Russian press has taken up the crusade, emphasizing that those who prevail in court frequently win the battle but lose the war because of their inability to enforce the judgment (e.g., "Ispolnitel'nyy risk" round-table in Rossiyskaya gazeta, November 13, 2002).

\footnotetext{
${ }^{3}$ A 1997 survey of 328 industrial enterprises found that 70 percent of these enterprises had been to court within the past year (Hendley, Murrell, and Ryterman, 2000). A separate survey of 269 enterprises by a team of economists in the late 1990s found that 58.4 percent believed that the courts could be used to enforce contracts (Johnson et al., 2000, p. 503). The report characterized this as a low level of trust in the courts, especially when compared to the results for the East European countries that also were surveyed (Poland, Slovakia, and Romania), but it can also be seen as reflecting a generally positive attitude. At the same time, I am more convinced by the behavioral evidence I collected with my colleagues than by the attitudinal evidence from the Johnson et al. survey.

${ }^{4}$ For a nuanced analysis of the role of organized crime in Russian business, see Radaev (1999, p. 37). He concludes that "the opinion of the thorough-going criminality of Russian business is largely the product of 'excitation' on the part of the mass media which ... is seriously exaggerating the scope of this phenomenon."
} 
But how accurate are these impressions? Litigants the world over grouse about the implementation of court judgments (e.g., Tyler, 1997, pp. 873-874; Baldwin, 1997, p. 128; Whelan, 1990). Perhaps difficulties in collecting are inevitable. After all, if the debtor-defendants involved had been amenable to paying, the dispute would never have ended up in court. In this article, I begin by laying out how the system of enforcing judgments is supposed to work in Russia and then contrast it with the reality of what happened in 100 concrete cases. This allows me to assess the veracity of the common wisdom that enforcing arbitrazh court judgments is virtually impossible and to investigate what strategies Russian managers use when trying to get debtor-defendants to comply with arbitrazh court decisions.

\section{METHOD OF INVESTIGATION}

Studying the implementation of court judgments is notoriously difficult. $^{5}$ Though laymen often think that courts keep records on enforcement, most courts do not. ${ }^{6}$ Once the judgment has been rendered, the court's work is generally finished. Judges may be disgruntled when debtors flout their decisions, but there is little that they can do to stem this tide (Elwell and Carlson, 1990, p. 511). Those of us interested in whether the putative victors actually collect any money-notwithstanding having a decision in their favor-have to track down the parties ourselves. The logistical complications and expense associated with doing so helps explain why so few scholars have undertaken these sorts of studies (see Baldwin, 1997, pp. 128150; Elwell and Carlson, 1990, pp. 512-521).

The Russian arbitrazh courts do not keep records on the enforcement of their judgments. The skepticism about collection that judges routinely expressed in conversations with me reflected the pessimistic attitude toward collection found in the Russian press and was, no doubt, influenced by the grumbling of the creditors that appear before them. Neither these judges nor their bureaucratic superiors have ever undertaken a systematic study of the implementation of arbitrazh court decisions. ${ }^{7}$ My study represents the first, albeit preliminary, effort to do so.

\footnotetext{
${ }^{5}$ The lack of reliable data on enforcement is not unique to Russia. In his study of the implementation of small claims courts decisions in England and Wales, Baldwin (1997, p. 129) found the existing information to be "partial, inaccurate, and untrustworthy."

${ }^{6}$ An exception is the U.S. small claims courts, which are supposed to keep track of payments. But the responsibility for notifying the courts falls on the creditor-plaintiffs, who frequently neglect to do so (Weller, Ruhnka, and Martin, 1990, p. 16).

${ }^{7}$ The Russian press occasionally reports summary statistics on enforcement, but fails to provide enough information to allow the reader to make sense of them. For example, on February 28, 2003, the website for news of Russia's regions, www.regions.ru, published a brief report from the chief bailiff (glavnyy sudebnyy pristav) of Chelyabinsk Oblast' laying out the number of cases that had been brought to the bailiffs during 2002 and the amount of money collected through enforcement of court judgments. But it did not detail how many total cases had been decided by the Chelyabinsk courts that year or the subject matter of the cases. Absent such information, the reported statistics are almost meaningless.
} 
My research plan called for me to assemble a set of 100 non-payments cases, drawn equally from the arbitrazh courts in Moscow, Yekaterinburg, and Saratov, and then to contact the participants to find out what happened after they left the courthouse. Their contrasting sizes as well as the differences in the political economy of the regions from which their cases are drawn make them good comparative cases, though my familiarity with them as a result of prior research added to their appeal. Table 1 summarizes the key features of the three courts and Table 2 presents an overview of the political economy of the regions.

Access to the three courts, the case files, and the participants was not easy to secure. Though the constitution ostensibly guarantees public access to courts, entry is generally limited to participants. Moreover, suspicion of foreigners has outlived the Cold War. I have been doing regular field work in the arbitrazh courts in Moscow, Yekaterinburg, and Saratov since 1996 and am personally acquainted with the chairmen of these courts and many of the judges, but I still need permission from their bureaucratic superiors in Moscow for each project. The hierarchical structure and the reluctance to take full responsibility for what might come from scholarly scrutiny is a holdover from the Soviet era. As in prior years, an introductory letter from the Higher Arbitrazh Court got me in the door of the trial courts. The wording of the letter was purposely vague, allowing me access to archived records, ongoing cases, and courthouse personnel for interviews.

I spent a month at each of the courts during the first half of 2001. After obtaining clearance from the chairman of the court, I worked with a lowlevel court official who funneled case files to me from the archives. Experience had taught me that I would have little control over case selection and that obtaining a truly random sample would be impossible. Adjusting to the situation, I ensured comparability by imposing two conditions on selection. First, the case had to involve an unpaid debt from one enterprise to another. I framed the request in the language used in the statistical reporting forms in order to eliminate any uncertainty. ${ }^{8}$ Second, I asked for cases that had been decided six to nine months earlier. This allowed the victors sufficient time to make some effort at collection, ${ }^{9}$ but ensured that the economic constraints on participants would be similar. The complete indifference to my research of the young women who brought the case files to me left me convinced that they had no interest in skewing the case selection in any particular direction. ${ }^{10}$

After collecting information about the cases, I sought out the petitioners to find out what happened after they got the judgment and how satisfied they were with the outcome. In an effort to maximize response rates, I worked through local law-related non-governmental organizations

\footnotetext{
${ }^{8} \mathrm{~A}$ literal translation of the phrase is: "calculations for production, goods, services" (raschety za produktsiyu, tovary, uslugi).

${ }^{9}$ The order ostensibly compelling payment (ispolnitel'nyy list) that is routinely issued by the court at the conclusion of non-payments cases is valid for six months (Arbitrazhnyy protsessual'nyy kodeks Rossiyskoy Federatsii, art. 201, 1995, henceforth APK, 1995).
} 


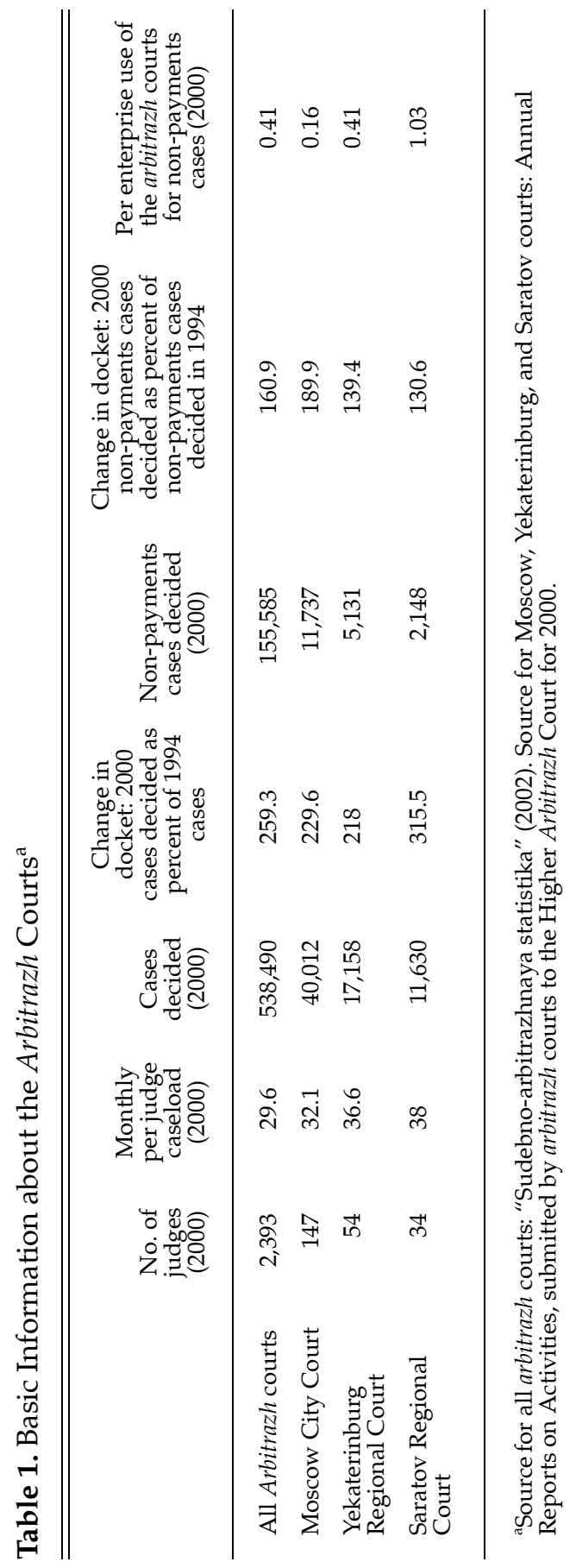




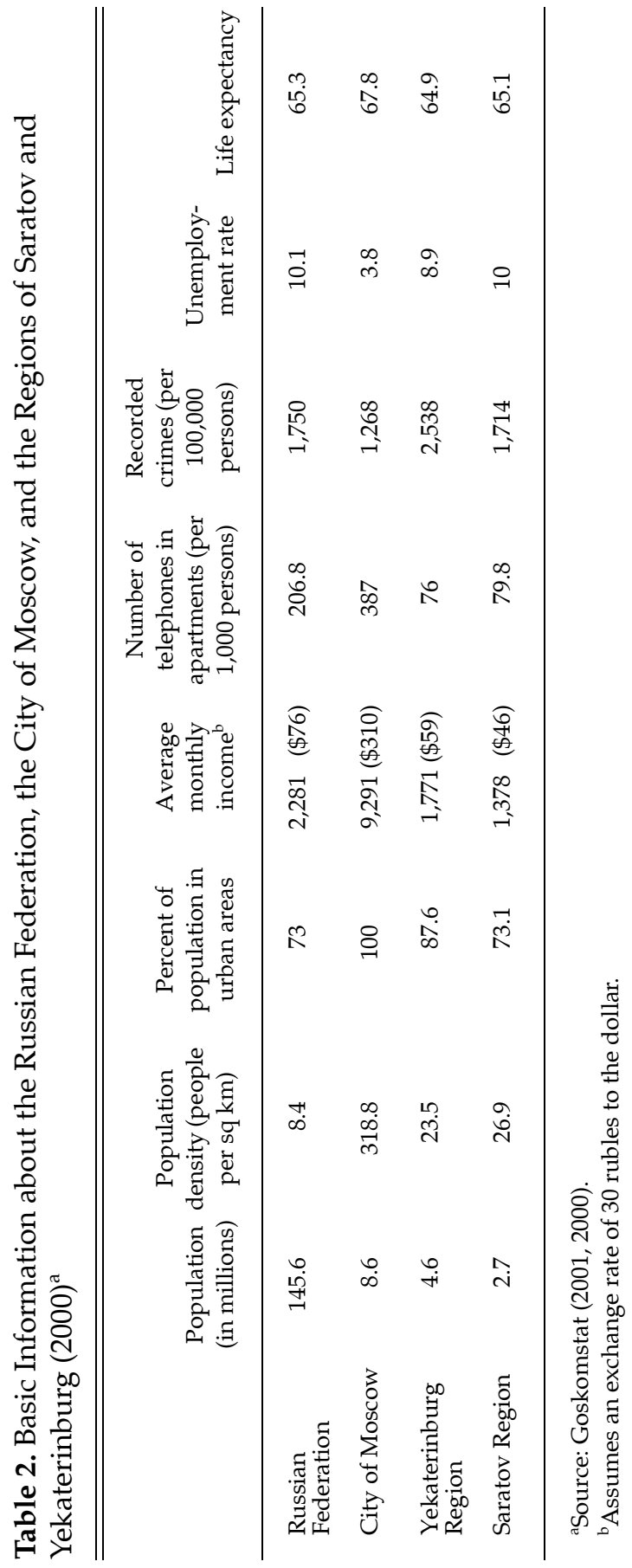


with which I had been loosely affiliated since the mid-1990s. ${ }^{11}$ Prior experience doing research in enterprises had taught me how skittish managers were when dealing with foreigners (especially Americans). Though my Russian is fluent, it is accented. I reasoned that native speakers would have better luck. In each location, I worked with law students affiliated with the NGOs. I trained them to work with a standard interview protocol that I had developed. The interview was designed to take no longer than 30 minutes. Almost all (83 percent) of the conversations took place on the phone. The questions focused mostly on the specific case, but also asked about their prior use of the arbitrazh courts. I carefully avoided any questions that could be perceived as delving into commercial secrets. Even so, some (eight) petitioners declined to answer any of the follow-up questions. $^{12}$

\section{OVERVIEW OF SAMPLE}

Before turning to the question of enforcement, a brief overview of the sample is in order (Hendley, forthcoming). Several patterns are clearly discernable. Like businessmen elsewhere, Russian managers try to reach some sort of accommodation with their customers before initiating litigation. Most (84 percent) of the creditors in my sample had attempted to settle the dispute amicably and had taken their time about doing so. On average, 11 months elapsed from the time the debt arose until the lawsuit was filed (see Table 3). ${ }^{13}$ For the most part, creditors are using the courts to go after relatively small amounts. Over 80 percent of the cases involved less than 500,000 rubles, which, at the 2000 exchange rate of 30 rubles to the dollar, works out to about $\$ 16,667$ (see Table 4 ). These lawsuits tend to involve trading partners with minimal histories together. It follows that the bigticket disputes between long-term partners, which surely exist, are being handled more informally, with the goal of preserving the relationship. The

\footnotetext{
${ }^{10}$ The courts varied in how they maintained records. The Moscow and Saratov courts have central archives. Cases are filed chronologically but the judge must fill out a file card for each indicating the category of dispute. Using them, the archivist was able to pull out cases involving inter-enterprise debt and give them to the secretary who was helping me. I was not allowed to have any contact with the archivist. In Yekaterinburg, each judge stores his own case files. The secretary helping me gathered cases from the judges who heard debt cases.

${ }^{11}$ In Moscow and Yekaterinburg, I worked with public interest law firms that help citizens enforce their rights in civil courts (with a particular emphasis on labor rights). In Saratov, I worked with a broad-based legal reform center. I have known the people involved in these three centers since the early 1990s.

${ }^{12}$ Only one of these non-respondents was from Moscow. Four were from Yekaterinburg, and the remaining three were from Saratov. No easy explanations for why these enterprises refused to respond emerge from the data. The only distinguishing characteristic this group shared was a higher concentration of large enterprises as plaintiffs. While 45 percent of the cases in the sample were brought by large enterprises, five of the eight non-respondents (62.5 percent) were large enterprises. It is possible that these enterprises had more bureaucratic controls than did smaller enterprises.

${ }^{13}$ Article 196 of the Civil Code gives creditors three years to collect their debts.
} 
Table 3. Time Lapse Between Non-Payment and Initiation of Litigation among Sample of 100 Cases-Number of Cases (percentage by region) ${ }^{a}$

\begin{tabular}{lcccc}
\hline & All cases & $\begin{array}{c}\text { Moscow } \\
\text { (percent) }\end{array}$ & $\begin{array}{c}\text { Yekaterinburg } \\
\text { (percent) }\end{array}$ & $\begin{array}{c}\text { Saratov } \\
\text { (percent) }\end{array}$ \\
\hline Within 1 month & 1 & $1(3)$ & 0 & 0 \\
2-6 months & 26 & $10(30)$ & $9(26)$ & $7(21)$ \\
7-12 months & 20 & $7(21)$ & $9(26)$ & $4(12)$ \\
13-24 months & 36 & $10(30)$ & $10(30)$ & $16(48)$ \\
25-36 months & 16 & $4(12)$ & $6(18)$ & $6(18)$ \\
\hline
\end{tabular}

a Source: Data drawn from author's fieldwork.

${ }^{\mathrm{b}}$ The Moscow results exclude one case for which information is unavailable.

Table 4. Amounts of Petitions in Sample of 100 Non-Payments Cases (percentage of cases in region in particular category) ${ }^{\mathrm{a}}$

\begin{tabular}{lcccc}
\hline \hline & All & $\begin{array}{c}\text { Moscow } \\
\text { (percent) }\end{array}$ & $\begin{array}{c}\text { Yekaterinburg } \\
\text { (percent) }\end{array}$ & $\begin{array}{c}\text { Saratov } \\
\text { (percent) }\end{array}$ \\
\hline Less than 5,000 rubles $(\$ 167)$ & 11 & $4(12)$ & $5(15)$ & $2(6)$ \\
$\begin{array}{l}\text { From } 5,001 \text { to } 50,000 \text { rubles } \\
(\$ 167 \text { to } \$ 1,667)\end{array}$ & 34 & $13(39)$ & $11(32)$ & $10(30)$ \\
$\begin{array}{l}\text { From } 50,000 \text { to } 500,000 \text { rubles } \\
(\$ 1,667 \text { to } \$ 16,667)\end{array}$ & 36 & $8(24)$ & $14(41)$ & $14(42)$ \\
$\begin{array}{l}\text { From } 500,000 \text { to } 2.5 \text { million rubles } \\
(\$ 16,667 \text { to } \$ 83,333)\end{array}$ & 17 & $6(18)$ & $4(12)$ & $7(21)$ \\
$\begin{array}{l}\text { Dollar demands }(\text { ranging from } \\
\$ 200,000 \text { to over } \$ 4 \text { million) }\end{array}$ & 2 & $2(6)$ & 0 & 0 \\
\hline
\end{tabular}

aSource: Data drawn from author's fieldwork.

creditors in my sample were experienced litigators. During 2000, each had, on average, filed 18 lawsuits in the arbitrazh courts. Almost without exception, they prevailed, often receiving the full amount demanded in the original complaint (see Table 5). Most (84 percent) of the creditors were represented in the arbitrazh proceedings, and the data indicate that being represented was beneficial, i.e., that the chances of getting less than the amount originally demanded were less for creditors who were represented.

Certain aspects of creditors' experience in the arbitrazh courts stand out as well. Perhaps the most striking are the low costs associated with 
Table 5. Case Outcomes in Sample of 100 Non-Payments Cases as Compared to the Amount Demanded in the Original Petition (percentage of cases for region with given outcome) ${ }^{a}$

\begin{tabular}{lcccc}
\hline \hline & All & $\begin{array}{c}\text { Moscow } \\
\text { (percent) }\end{array}$ & $\begin{array}{c}\text { Yekaterinburg } \\
\text { (percent) }\end{array}$ & $\begin{array}{c}\text { Saratov } \\
\text { (percent) }\end{array}$ \\
\hline Less & 35 & $9(29)$ & $12(35)$ & $14(42)$ \\
Same & 47 & $17(55)$ & $16(47)$ & $14(42)$ \\
More & 6 & $2(6)$ & $3(9)$ & $1(3)$ \\
Settled & 6 & $1(3)$ & $2(6)$ & $3(9)$ \\
Dismissed & 4 & $2(6)$ & $1(3)$ & $1(3)$ \\
\hline
\end{tabular}

a Source: data drawn from author's fieldwork.

${ }^{b}$ The Moscow results exclude two cases for which information is unavailable.

commercial litigation in Russia. Few participants bother to hire outside lawyers, preferring to rely on in-house counsel or to forgo the use of lawyers entirely. The up-front filing fees, which are calculated as a percentage of the amount at issue, are less of an obstacle than they first appear to be because they can be put off until the conclusion of the case if the petitioner is cash-poor, and if the petitioner prevails, these fees are simply tacked onto the amount owed by the defendant. The need to master the procedural intricacies of the system is mitigated by the willingness of arbitrazh judges to help uninitiated and even incompetent litigants through the process. This coddling may hamper the growth of the arbitrazh courts institutionally, but it unquestionably acts to even the playing field between experienced and unexperienced players. As a result, neither size nor financial wherewithal plays the decisive role that might be expected.

Virtually all (87 percent) of the firms in the sample were motivated to sue in order to recover money owed to them (see Table 6). More intriguing are the less obvious catalysts. Some issues that would probably emerge as significant in an adversarial setting, such as that in the United States, fade in importance in Russia. Very few creditors use litigation as a signal to other customers of the parameters of acceptable behavior. Even fewer regard litigation as a mechanism for punishing an undisciplined trading partner. Factors that are specific to Russia turn out to be more relevant. The uncertainty of the economic transition left the rules about when debts could be written off in flux. The vagaries of the tax code in effect during the 1990s, which some managers believed resulted in a tax rate of over 100 percent of income, created a powerful incentive to hide income (Berkowitz and Li, 2000). One popular method was to pad financial records with fictitious debts in order to create the impression of no income (and, therefore, no tax 
Table 6. Motivations for Initiating Litigation in Sample of 100 NonPayments Cases: Percent of Enterprises Responding Affirmatively ${ }^{a}$

Did the petitioner file the lawsuit in order to ...

recover money owed to it?

get the judgment for accounting purposes?

get the judgment for tax purposes?

send a message to other customers that not paying is unacceptable?

punish the debtor because its behavior indicated an intolerable lack of respect?

a Source: Data drawn from author's fieldwork. Results exclude nine enterprises that refused to respond to the question.

obligation). In conversations predating the study, some enterprise managers had reported that they preferred to have a court judgment in hand before writing off debt because it lessened the chances of challenges from the tax inspectorate. Along similar lines, I was also told that they occasionally resorted to the courts-even when the chances of collecting on a judgment were slim-in order to prove to the state authorities the genuineness of a debt. ${ }^{14}$ According to managers, an arbitrazh court judgment was viewed as definitive proof that a debt was not illusory. Thus it is not surprising that a significant percentage of the creditors in my sample reported that they were motivated to litigate by accounting (35 percent) or tax (28 percent) concerns.

\section{COLLECTING ON JUDGMENTS: HOW IT IS SUPPOSED TO WORK}

Once a decision is rendered, the victor must wait a month before taking affirmative action to collect. During this period, either party may file an appeal (APK, art. 135, 1995). If the debtor is amenable, it can pay voluntarily during that month. The parties may be in contact to work out a payment schedule or to come to a mutually acceptable accommodation. There is, of course, a danger that assets will mysteriously disappear during this period. To guard against this, the creditor can petition the court to freeze the defendant's assets. After a month, if the judgment remains unpaid, the

\footnotetext{
${ }^{14}$ In a macabre twist on this logic, it seems that some organized crime groups insist on an arbitrazh court judgment before involving themselves in debt collection (Volkov, 2002, p. 46; Hendley, Ickes, Murrell, and Ryterman, 1997).
} 
plaintiff may petition for an "enforcement order" (ispolnitel'nyy list) (APK, art. 198, 1995). No additional hearing is required; the judge's clerk issues these orders as a matter of routine. The plaintiff presents the ispolnitel'nyy list to the defendant's bank. If the defendant has sufficient funds in its account, the amount of the judgment is immediately transferred to the plaintiff's bank account (Yakovlev and Yukov, 1999, pp. 408-414).

Difficulties arise when the funds in the defendant's account are insufficient to cover the judgment. Many Russian enterprises are struggling to stay afloat, and so maintain low cash reserves. A significant number of these enterprises owe money everywhere-to other enterprises and to the tax authorities. ${ }^{15}$ Consequently, they work at keeping their bank accounts empty since any money that appears quickly disappears to draw down these debts (Hendley, 1999). The reasons why enterprises have little money in their bank accounts are complicated and often have little to do with escaping responsibility for a single lawsuit.

If presenting the ispolnitel'nyy list to the debtor's bank fails to yield the desired result, then the creditor can pursue the debt by using legalistic and / or more informal methods. Within the Russian legal system, bailiffs (sudebnyye pristavy) are charged with enforcing judgments (Kahn, 2002). Unpaid judgments are not automatically forwarded to the bailiffs; creditors who want to make use of the sudebnyye pristary must take the initiative. Once brought into the case, bailiffs are charged with making their best efforts to recover the amount of the judgment for the creditor. How well they succeed is open to debate. The powers of the sudebnyye pristavy were expanded as part of a reform of the service in the late 1990s but they cannot squeeze blood from a turnip. ${ }^{16}$ If a debtor has no ready cash and no easily saleable equipment, then the efforts of the bailiffs may come to naught. Some Russian managers and even some arbitrazh judges question whether the bailiffs are, in fact, genuinely attempting to recover the amounts owed; they contend that the sudebnyye pristavy are too quick to declare defeat and are unwilling to put in the hard work necessary to auction off industrial equipment or ferret out hidden assets. To be fair, bailiffs are overworked; many juggle several hundred cases at a time (Kahn, 2002, p. 159). Quite understandably, some bailiffs prefer to tackle the simpler cases involving child support obligations and various types of administrative fines, and, as a result, the more complicated non-payments cases generated by the arbitrazh courts tend to languish (Kahn, pp. 164-65). If either side is dissatisfied with the behavior of the sudebnyye pristavy, it can make a formal complaint to the court. Such complaints increased dramatically following the reforms, indicating both that the process has become more complicated and that more enterprises are using it. ${ }^{17}$

\footnotetext{
${ }^{15}$ Article 855 of the Civil Code prioritizes debt. Creditors-even those holding valid court judgments - cannot be paid until tax and other governmental liabilities have been extinguished and until all back wages have been paid.

${ }^{16}$ The parameters for the bailiff service were established in two laws passed in 1997 (Ob ispolnitel'nom, 1997; O sudebnykh, 1997).
} 
Either in concert with or in place of these legalistic remedies, creditors have a variety of more informal methods available to them in their quest to get debtors to pay arbitrazh court judgments. Negotiation continues to be an option. In many Western legal systems, obtaining a judgment serves as the basis for a new round of haggling between the parties, though the bargaining position of the creditor depends on the existence of a viable threat that if the debtor fails to come through, the judgment will be enforced. Where the credibility of the enforcement system is uncertain, as in Russia, debtors may walk away from negotiations. In addition, creditors can call upon third parties to help them convince debtors to pay. Such actions can take a variety of forms, ranging from calls from representatives of sectoral business associations to less benign visits from representatives of private enforcement firms accompanied by threats of physical violence or worse.

On paper, the range of options available to creditors in Russia is analogous to those available to creditors in other market economies. There is always a "gap" between the law on the books and its practice. In Russia, this "gap" has sometimes seemed more like a chasm. I explore the reality of how judgments of the arbitrazh courts are enforced by exploring what the 100 creditors in my database did to get the money owed to them and how satisfied they were with the experience.

\section{COLLECTING ON JUDGMENTS: WHAT ACTUALLY HAPPENS}

The majority (64 percent) of creditors in my sample succeeded in recovering some or all of the arbitrazh court judgment. ${ }^{18}$ On average, they received almost half (46.7 percent) of the amount awarded (see Table 6). How are these results to be interpreted? Is the glass half full or half empty? Judged objectively, recovering only half of the amount awarded would seem to be a rather abysmal record. But in the Russian context, such an assessment would be overly harsh. The common wisdom would have us believe that most creditors fail to collect anything after receiving a judgment in their favor. My sample suggests that such rhetoric is hyperbolic. Indeed, just the opposite would seem to be true; most creditors have something concrete to show for their experiences in the arbitrazh courts. Yet

\footnotetext{
${ }^{17}$ Such claims grew from 223 in 1998 to 422 in 1999 in the Moscow court. The increase was steeper in Yekaterinburg and Saratov. In Yekaterinburg, claims went from 47 in 1998 to 203 in 1999, and in Saratov, they went from 19 in 1998 to 143 in 1999. Kahn (1999, pp. 170-171) argues that "[ $t]$ he formal system of judicial oversight works poorly." He believes that judges are not interested in, or committed to, monitoring the bailiffs, because they have no financial stake in enforcement and because they feel that the poor legal training of the bailiffs risks opening a virtual Pandora's box of procedural violations that would occupy too much of the judges' time if they were fully explored.

${ }^{18}$ All percentages reported in this section exclude the nine cases in which the creditor refused to respond to follow-up questions.
} 
a record of recovering less than half of the court judgment leaves considerable room for improvement.

When the several cases in which the debtors paid voluntarily after being held liable are removed, the average percentage of the court judgment recovered drops down to 43.5. This mean percentage reflects an allor-nothing pattern. As Table 7 shows, 76 creditors fall into this category of either getting the full amount of their judgment or ending up with nothing. Indeed, in Saratov, there was only one case involving non-voluntary payment in which the creditor did not get either nothing or 100 percent of the judgment. Within the sample, there are, unfortunately, more in the emptyhanded group (43 of 76, or 56.6 percent) than in the fully-satisfied group (33 of 76, or 43.4 percent). Precisely how they went about recovering (or not recovering) these amounts is discussed below.

What is most startling about the data on the percentages recovered by the creditors in my sample is the regional skewing. Those in Moscow made out much better than those in Yekaterinburg or Saratov. On average, Moscow creditors took home about two-thirds of their judgments, whereas their counterparts from the hinterland got only about half as much. Comparing the results in Moscow and Saratov reveals a mirror image. While 19 Moscow creditors recovered 100 percent and eight got nothing, the situation was just the opposite in Saratov, where 20 creditors got nothing and six recovered the full amount of their judgments. What accounts for these results? The vagaries of sampling cannot be dismissed as a factor. Perhaps I somehow ended up with a bizarrely conscientious set of debtor-defendants in Moscow, though the fact that only two Moscow debtors paid voluntarily tends to undercut this explanation. The variation in economic conditions between Moscow and the rest of Russia is more likely at the root of the disparity in recovery rates. Table 2, which lays out some basic economic indicators as of 2000, when my research was carried out, endeavors to capture these differences. The economic depression experienced by the rest of the country during the 1990s was muted in Moscow. Its average wages were higher and its unemployment rate was lower than elsewhere in Russia. Moscow is the unquestioned financial center of Russia and has the highest concentration of companies..$^{19}$ It would not be surprising if its business culture was also a step ahead of the rest of Russia. Perhaps, while reneging on debt remains acceptable in much of Russia, Moscow businessmen have begun to impose informal sanctions on welshers. A full analysis of the reasons for the regional variation is beyond the scope of this article, but certainly deserves additional research.

\footnotetext{
${ }^{19}$ According to Goskomstat (2000), 18.8 percent of all enterprises registered in Russia are located in Moscow.
} 


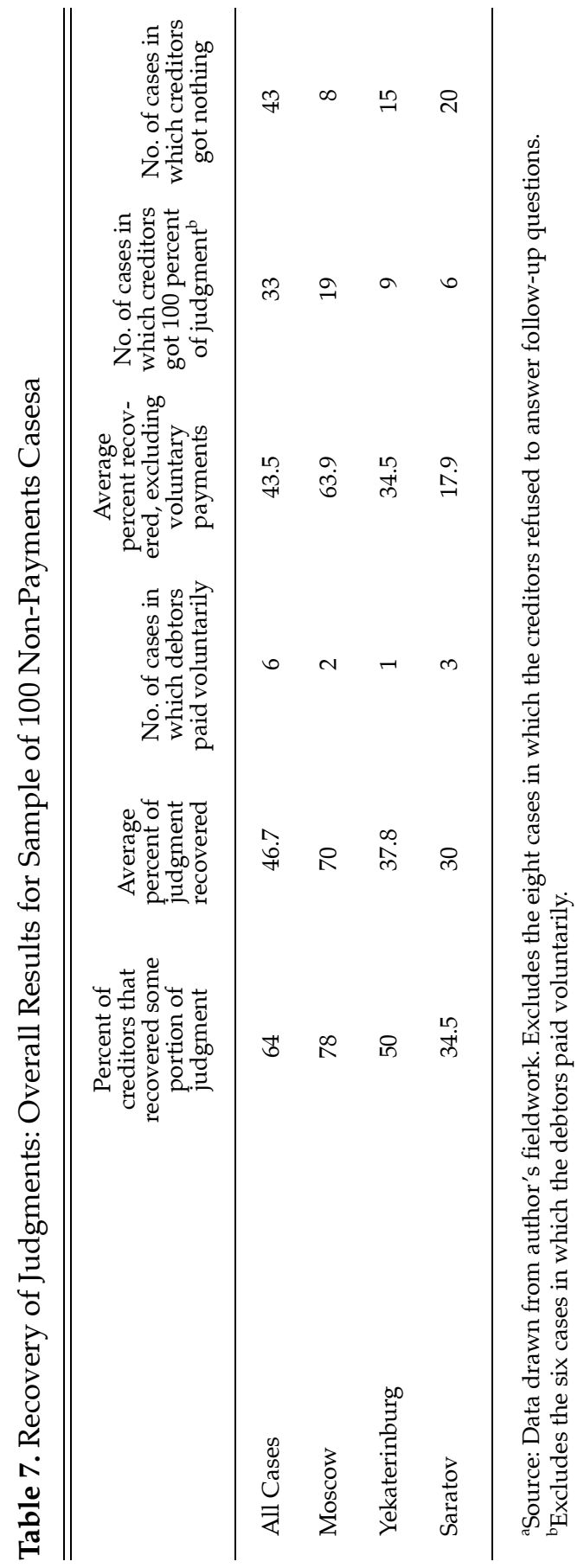




\section{Preemptive Action}

Given that the enterprises in my sample appeared frequently before the arbitrazh courts, they were surely aware of the difficulties associated with enforcing judgments. Yet relatively few of them took preemptive steps to protect their position. As I noted above, there is a mechanism by which petitioners in arbitrazh courts can, in essence, freeze the defendants' assets in order to guarantee that they will still be available when judgment is rendered. Such a petition can be made at any point in the case. Though this procedural mechanism would seem to be ideally suited to the uncertainty that faces creditors in post-Soviet Russia, only ten of those in my sample made use of it.

What explains this disdain? My conversations with arbitrazh judges during the field work in the spring of 2001 revealed that they had imposed a high burden of proof on plaintiffs seeking these orders. According to the procedural code, the task is to convince the court that, absent such an order, the plaintiff will likely be unable to collect on the judgment (APK, art. 76, 1995; Yakovlev and Yukov, 1999, pp. 180-182). When the 1995 code was first passed, judges took note of creditors' suspicions and, more often than not, granted such petitions. By 2001, the bar had been raised. Judges now required proof that debtor-defendants were not going to pay. Thus, creditors found themselves in a classic "catch-22" situation; such proof became available only when the debtors lived up to the creditors' suspicions and failed to pay. By that time, it was too late. Judges rationalized their strict standards on several grounds. They were understandably reluctant to tie up the working capital of defendants who had not yet been found liable (this was especially problematic for banks). In addition, they claimed that their hands were tied by a decree of the Higher Arbitrazh Court that mandated these stricter standards.

Regardless of the reasons for this change in judicial behavior, it has certainly had a chilling effect on creditors. Fewer and fewer bother making the attempt to freeze assets. When they do so, it is likely to be against a new customer. For five of the creditors that sought such an order, it was their first interaction with the defendant-customers. Two others had been working with the customers in question for only a few years. Only one involved long-term trading partners. (Two of the enterprises that sought these orders refused to respond to follow-up questions about the relationship.) In addition, smaller companies are more likely to be involved, both as the plaintiff and the defendant. Seven of the ten creditors that sought to freeze assets were small companies, and, somewhat coincidentally, seven of the ten debtors against whom these orders were sought were also small companies. Their disproportionate use of the freezing mechanism makes sense. ${ }^{20}$ Small companies, such as closed joint-stock companies or limited

\footnotetext{
${ }^{20}$ Small companies constitute 34 percent of plaintiffs and 48 percent of defendants in the sample.
} 
liability companies, tend to be less financially stable than the larger, open joint-stock companies. It is not surprising that they are more aggressive when pursuing delinquent customers. Likewise, when small companies are defendants, the creditors seeking to be repaid are understandably skittish. These small companies come and go with startling frequency, sometimes vanishing without a trace, and creditors are reluctant to trust them.

I had thought that the size of the unpaid debt would affect the likelihood of seeking an order to freeze the defendant's assets, but the data indicate otherwise. The distribution of petitions by size for the subset of cases where these petitions were made is substantially the same as for the overall sample (see Table 4).

What happens when creditors ask for a court order freezing debtors' assets? The effect of the ratcheted-up burden of proof can be seen in the success rate. Only four of the ten creditors that sought these orders got them. But perhaps the purpose of these petitions is less to freeze the debtors' assets and more to signal a willingness to go to the wall to recover the debt. After all, the creditors who made these petitions were, with only one exception, experienced litigators. As such, they knew only too well that the odds were against them. But by making the petition, they put both the court and the customer on notice. In the end, this seemed to serve them well. Of the ten creditors that sought these orders, half ended up recovering the full amount of their judgment-a better record than the sample as a whole. Interestingly, whether they got the order did not seem to matter much in the final analysis. Of the four that sought and received judicial protection, two recovered 100 percent of the judgment, but two ended up with nothing. Of the six whose hopes for judicial protection were dashed, three recovered 100 percent of the judgment, one recovered 50 percent of the judgment, one got nothing, and one refused to respond to questions.

\section{Voluntary Payment}

Turning now to post-judgment efforts at enforcement, my sample reveals a core of truth behind the common wisdom that debtors rarely pay arbitrazh court judgments voluntarily. Of the 100 creditors I studied, only six paid without some sort of prodding, whether informal or more legalistic. This confirms the "come and get me" attitude that I had sensed when talking with managers when carrying out enterprise case studies (Hendley, 2001). These managers did not dispute their liability, but felt that it was up to the creditor to force them to pay. They often commented that they were waiting for the bailiffs (sudebnyye pristavy) to show up. Yet when I asked them about their accounts receivable, they complained bitterly about the unwillingness of their own customers to pay on time and about the impossibility of getting arbitrazh court judgments enforced. For some reason, they seemed unable to connect the dots to see that this lack of reciprocity within the system was crippling it. No state can afford to enforce every single judgment of its courts affirmatively. The civil system works because most 
litigants pay voluntarily. The willingness to pay is motivated by a desire to avoid community censure and by a fear of the coercive power of the state (e.g., Tyler, 1990). In post-Soviet Russia, reputational sanctions for not paying debts have been slow to develop. The widespread nature of the economic crisis has given rise to a business culture in which non-payment has become the rule rather than the exception. ${ }^{21}$ As a result, the burden on the state to affirmatively enforce civil judgments is unusually high, and the state has staggered under the burden.

My research suggests that when debtor-defendants pay voluntarily, they tend to pay the full amount of the judgment. This is what happened in five of the six cases in which the debtor paid voluntarily. In the case that was the exception, the defendant paid 50 percent of the judgment (and the creditor made no effort to collect the remainder of the debt).

What characteristics do these six disputes in which the debtor-defendants paid voluntarily share? Most of them (five of six) were cases that had proceeded to judgment. This surprised me. I had expected that most would be cases in which the dispute had been settled before the court rendered its judgment. More specifically, I had thought the category would be dominated by cases in which debtors were motivated to pay by the filing of the lawsuit. My notes on the case files indicated that the sample included three such cases. But only one of these debtors actually followed through and paid. In the two other cases, the debtor apparently reneged on his promise once the threat of litigation disappeared. In the follow-up interviews, the creditors reported that they never received anything-none of the strategies discussed below yielded results.

Working out why these particular disputes resulted in voluntary payments is complicated by the fact that there was nothing much distinctive about this subset of cases. Rather, they generally replicated the overall sample. The creditors were represented by counsel and were experienced litigators. All had been in and out the arbitrazh courts repeatedly during 2000 and had stellar track records. ${ }^{22}$ The amounts involved basically mirrored the distribution for the sample. Likewise, the organizational structure of the litigants was analogous to that for the sample.

Perhaps two key differences between this subset and the overall sample can provide some insight. Unlike the sample, those involved in these cases had a sustained history together. Whereas the litigants within the sample had generally been working together for only a few years, those in these voluntary-payment cases had been working together, on average, for 10 years. Also, the time between when the debt arose and when the lawsuit was filed was shorter for these cases. Two-thirds of the debts in these voluntary-payment cases arose two to six months before the lawsuit was

\footnotetext{
${ }^{21}$ This represents a natural evolution from Soviet-era business and legal culture, in which an ability to get around (oboyti) the rules was a highly desired quality in managers.

${ }^{22}$ The two Moscow creditors who were paid voluntarily refused to answer questions about their litigation history. The four other enterprises had been to court, on average, 17 times during 2000 (which mirrors the result for the entire sample) and had won all of their cases.
} 
initiated, which was substantially higher than the incidence of such cases for the overall sample (26 percent). What conclusions can we draw from these findings? They suggest that the voluntary-payment cases tend to involve companies that know one another well and know that when payment is not forthcoming right away, negotiations alone are unlikely to pry the funds loose. Instead, payment is accomplished through litigation. Of course, the small number of cases involved prevents any sort of definitive conclusions.

\section{Strategies to Compel Compliance with Court Judgments}

The sad reality for Russian creditors is that few debtor-defendants pay without some nudging. The pressure applied can take a variety of forms and can emanate from different sources. In this report, I confine myself mostly to discussing legalistic strategies, such as relying on court orders or bailiffs. Among the 100 non-payments cases I studied, these were the two most commonly used strategies.

But my follow-up questions to the creditors explored other possible methods of recovering. The scholarly literature emphasizes the role of third parties in debt collection (e.g., Volkov, 2002). My data suggest that this emphasis may have been overdrawn. Only two creditors asked third parties to help them persuade debtors to pay. One was from Yekaterinburg and the other was from Saratov. The strategy did not bear fruit for either of them. The Saratov creditor sought help from both a benign third party and a "private enforcement" firm. It is possible that enterprises were reluctant to reveal their reliance on "private enforcers," given the connotation of illegality and coercion that goes with these practices. Yet this would not explain why so few firms reported using any sort of third-party assistance, such as business associations, government officials, or a wellrespected businessman known to both sides. I am more inclined to think that creditors regard the collection of the sort of small debts over which they had sued as a matter between them and their delinquent customers. The involvement of outsiders is limited to those empowered by the state to handle disputes, such as courthouse personnel and bailiffs. Perhaps bringing in third parties-whether benign business associations or more menacing groups that use threats of violence to force payment-is reserved for disputes with more at stake (whether money or corporate control). My intention is not to deny the obvious reality that organized crime is intertwined with Russian business, but to question how involved these organized crime groups are in debt collection. ${ }^{23}$

Post-judgment settlement talks were more popular among the creditors in my database. In some legal systems, a judge's decision is seen as establishing a basis for further negotiations between the parties. Each side

\footnotetext{
${ }^{23}$ The results of Radaev's surveys, which documented that relatively few Russian businessmen who have been confronted by "strong-arm methods" turn to outsiders for help (whether legal or extra-legal), tend to support my conclusion (Hendley, 1999, p. 57).
} 
has leverage. The victor obviously has the authority of the court on its side, while the loser can forgo its right to appeal in return for a reduction in the amount owed. While my closed-end questions did not allow for probing into the rationale behind settlement negotiations in Russia, it is safe to assume that creditors engage in them in an effort to get something out of their courtroom victories. Whether the threat of appealing the verdict is as potent in Russia as in adversarial systems like that of the United States, where appeals can drag on for years, is doubtful. But what creditor would not prefer to have some cash in hand rather than an unpaid judgment for more?

Typically, efforts at negotiating a settlement took place immediately after the court announced its decision, i.e., during the month when the defendant had the right to appeal. A significant portion (42.4 percent) of the creditors in my sample tried to reach such an accord. The odds of securing an agreement and having the defendant pay were not overwhelming-22 percent of the creditors that took this route got something for their efforts-but were high enough to provide an incentive to try. ${ }^{24}$ After all, the costs associated with trying to settle are negligible. Most (62.5 percent) of those that got something ended up with the full amount of the judgment. As we will see for the other strategies, the use of this strategy was skewed regionally. Oddly enough, it was both the most popular and the most unsuccessful in Saratov, where 23 creditors made the effort but not a single one of them recovered anything. Yekaterinburg creditors had more luck11 tried to settle with their debtor-defendants and seven were rewarded (at least partially) for their efforts. Only a few (two) Moscow creditors bothered to try settling, probably because they were confident of their ability to collect via court orders or bailiffs (see Tables 8 and 9).

\section{Court Orders}

When debtors failed to pay voluntarily, most creditors obtained a court order (ispolnitel'nyy list) that allowed them to siphon money directly from the debtor-defendants' bank accounts. The popularity of this strategy is not surprising. Obtaining the ispolnitel'nyy list requires no special effort by creditors. When funds are available, this process works smoothly; the amount of the judgment is transferred from the debtor's account to the creditor's. Arbitrazh courts automatically issue these orders a month after the decision, and creditors need only stop by the judges' chambers to get a copy. As Table 8 indicates, 77 of the enterprises in my sample got an ispolnitel'nyy list and reported that getting these court orders was routine

\footnotetext{
${ }^{24}$ The follow-up questions designed to elicit the creditors' assessment of post-judgment negotiations as a strategy produced somewhat contradictory results. While the vast majority (86 percent) told interviewers they would be "very likely" to try to negotiate settlements in the future, they indicated ambivalence for the strategy when asked to evaluate its effectiveness on a scale of 0 to 10 (where 10 equated to perfect effectiveness). The mean score for those who used the strategy was 4.5, and, in contrast to the evaluations of ispolnitel'nye listy and sudebnyye pristavy (see Tables 8 and 9), scores were consistent across all three regions.
} 


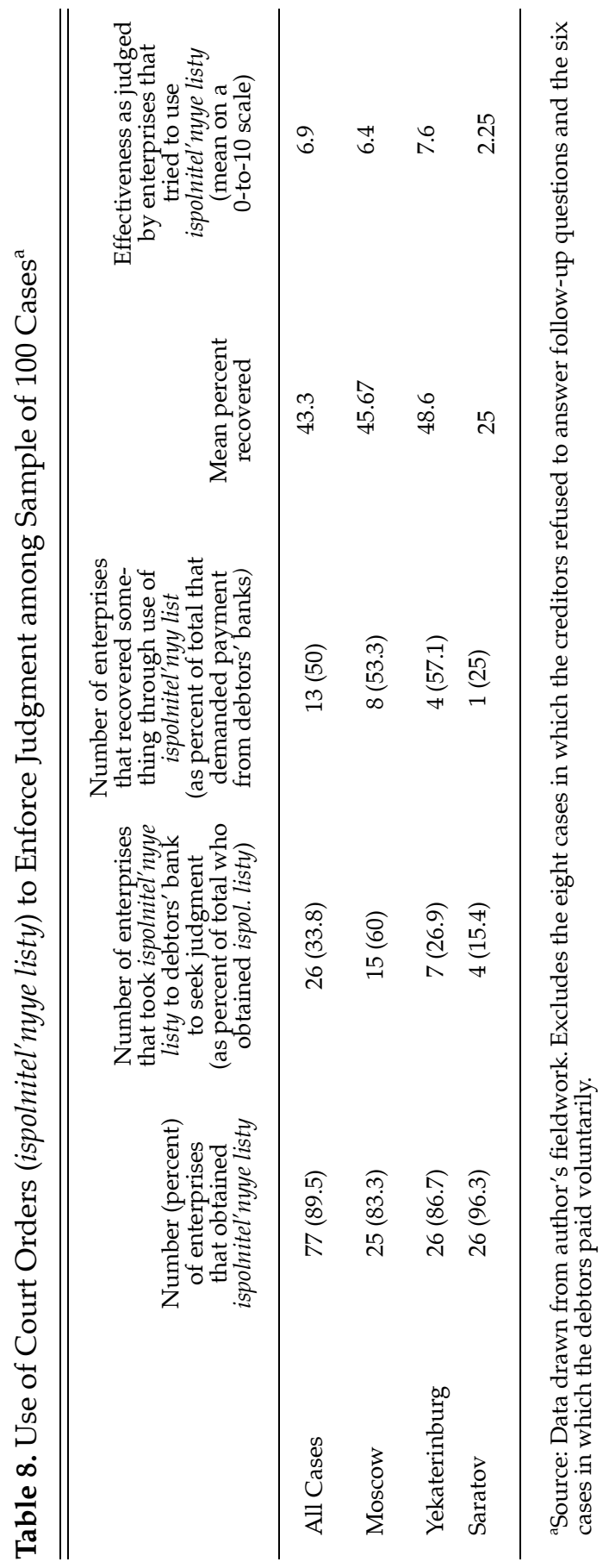


for them. When removing the defendants who paid voluntarily (six) as well as those who refused to respond to follow-up questions (eight), it becomes apparent that virtually all of the creditors got an ispolnitel'nyy list. Indeed, only eight creditors failed to do so.

But having this court order does not automatically translate into using it. When the data are examined more closely, it turns out that relatively few creditors made a genuine effort to enforce judgments through ispolnitel'nyye listy. These court orders are not self-executing, but must be taken to the banks where debtor-defendants have accounts. Table 8 reveals that a relatively small percentage of creditors take the necessary affirmative action. Most (66.2 percent) do nothing. Why? My prior research inside enterprises leaves me with no doubt that managers understand that doing nothing will yield nothing. Though the rule requiring these court orders to be taken to banks may strike readers as arcane, it is well-known to managers. Supporting this contention is the fact that having representation at the hearing has no noticeable effect on whether the creditor then presents the court order to the bank. ${ }^{25} \mathrm{~A}$ more compelling explanation is the pervasive skepticism among creditors about the likelihood of finding funds in defendants' bank accounts. Many Russian enterprises are cash-poor and their bank accounts are empty. Often there are already a number of judgments against the debtor, all of which take precedence over the new judgment. Perhaps the creditors in my sample who never bothered to present the ispolnitel'nyye listy to the banks for payment felt that doing so would be a waste of time.

At first glance, obtaining ispolnitel'nyye listy looks to be a quixotic strategy. Of the 77 enterprises that got such court orders, only 13 (16.9 percent) ended up actually recovering some or all of the judgment. But when the focus is narrowed to the smaller group of creditors that actually tried to collect using this strategy, the picture brightens up a bit. Half got something for their efforts. For the most part, creditors got either the full amount of the judgment or nothing, giving rise to an average recovery of 43.3 percent. ${ }^{26}$ Even though half ended up with nothing, they were not discouraged. When asked whether they would use an ispolnitel'nyy list in their next lawsuit, none of them backed away. Eighty percent said that they would "very likely" use this strategy, while the remaining 20 percent responded with a more equivocal "maybe." Not surprisingly, the less enthusiastic response came from enterprises that had been stymied in their efforts to recover using ispolnitel'nyye listy (with one exception). When asked to evaluate the effectiveness of ispolnitel'nyye listy on a scale from 0 to 10 , with 0 indicating complete ineffectiveness and 10 indicating complete

\footnotetext{
${ }^{25}$ The complete absence of representation arguably affects behavior. The ispolnitel'nyye listy languished unused in all of the eight cases in which both sides were unrepresented at the hearing. But the lack of representation was likely symptomatic of a deeper neglect of the dispute by both parties that continued after the decision was rendered.

${ }^{26}$ Of the 26 creditors who presented ispolnitel'nyye listy to debtors' banks, 23 (88.5 percent) ended up with all or nothing.
} 
effectiveness, these creditors were generally sanguine. As a group, they gave the strategy a positive score of 6.9. The scores did not seem to be linked to the results obtained in the case at hand, indicating that the managers interviewed were able to take the long view of the usefulness of ispolnitel'nyye listy.

What explains the more activist behavior of the enterprises that took the court orders to the banks of the debtor-defendants? What characteristics, if any, do they share? I had suspected that familiarity would play a role-namely, that those in first-time transactions would press harder for repayment because they had not yet built up any mutual trust and so would be more suspicious of one another. But the data reveal this to be an insignificant factor. But other common-sense explanations did pan out. The amount at stake matters, as does the organizational structure and size of the litigants. Not surprisingly, creditors seeking to recover debts in excess of 500,000 rubles (approximately $\$ 16,667$ ) are highly committed to the recovery process and are more likely than those who are owed lesser amounts to take the ispolnitel'nyye listy to the debtors' banks.

Making sense of the effects of organizational structure and size is more difficult. The fact that smaller firms (closed joint-stock companies) emerge as more enthusiastic about collecting their debts is logical. These firms often have a more precarious financial situation than large firms (open joint-stock companies) and so cannot afford to sit back and hope for the best. The reasons why state-owned enterprises are more likely to take action to collect on debts is less obvious. The small numbers involved make it difficult to draw any definitive conclusions. Perhaps the explanation lies in the widespread state budgetary shortfalls that complicated the lives of all state-funded organizations during the 1990s. Support for this contention can be drawn from the fact that state-owned enterprises and state agencies are more likely to be the defendants in the cases in which creditors take affirmative action than are private firms (either open or closed joint-stock companies). There are several possible interpretations of this finding. Perhaps creditors are concerned about the financial soundness of statefunded entities, thereby giving them a strong incentive to move aggressively at the outset. Creditors may also realize that these state-funded entities are not going anywhere, and while attaching a court order to their bank account compelling payment may not yield immediate benefits, it may eventually pay off. This explanation becomes more convincing when the treatment of state-funded entities is compared with that of individual entrepreneurs. My sample included five individual entrepreneurs as defendants, and none of the four creditors involved that responded to follow-up questions bothered to present their ispolnitel'nyy list to the banks. ${ }^{27}$ Regis-

\footnotetext{
${ }^{27}$ Only one of the four ended up with any portion of the judgment. This Yekaterinburg creditor secured 10 percent of the judgment through a post-decision settlement. One of the other creditors attempted to recover with the help of bailiffs. The remaining two took no affirmative steps to enforce their judgments and, not surprisingly, ended up empty-handed.
} 
tering as an entrepreneur provides no guarantee of financial wherewithal or geographic permanence. Just the opposite; individual entrepreneurs are often regarded as fly-by-night. When I was doing research in enterprises, a number of sales managers told me that they never extended credit to them; cash up front was the norm. Given this as background, the standoffish behavior of creditors holding overdue debt from individual entrepreneurs is logical. They seem to view these debts as dead losses and behave accordingly.

Although the likelihood of obtaining ispolnitel'nyye listy is fairly constant across the three regions, Table 8 reveals considerable regional variation in what happens thereafter. The situation in Saratov is quite dismal. Only four creditors made any effort to collect on their judgments by presenting their court orders to the relevant banks, and only one enjoyed any success. ${ }^{28}$ It is certainly no surprise that they regard using ispolnitel'nyye listy as an ineffectual strategy. Yet when asked whether they planned to use it when next in the arbitrazh courts, these Saratov creditors uniformly answered "very likely." The Moscow enterprises in my sample present a startling contrast. More than half of those that obtained court orders acted upon them, and within this group, a majority got something for their efforts. In fact, six of the eight that did so recovered the full amount of the judgment. It follows that these Moscow creditors' found ispolnitel'nyye listy to be more helpful than did their Saratov counterparts and planned to use them again.

Several puzzles emerge from these regional variations. What explains the disparity in the use of ispolnitel'nyye listy? Why did managers in Saratov and, to a lesser extent, in Yekaterinburg get these court orders and then fail to take full advantage of them? The small sample size makes generalizing hazardous, but the stark differences suggest that the patterns replicate those in the larger population. They hint at a divergence in institutional performance and in business culture between Moscow and the periphery. The Moscow enterprises would not bother going to the bank if they thought it was a waste of time, and, in fact, their efforts paid off. This suggests a normalization of business practices in Moscow. In other words, Moscow enterprises seem to be turning toward using banks to handle their routine business transactions, and that represents a shift away from the practice of avoiding banks for fear that funds would be whisked away by the tax authorities or other creditors. This, in turn, indicates that Moscow enterprises are more solvent than their counterparts elsewhere, a finding that the general statistics for the three regions tends to support (see Table 2). Enterprises in Saratov and Yekaterinburg seem to be clinging to the old strategies of avoiding banks. Presumably these managers let the ispolnitel'nyye listy languish because they believed that the debtors' bank accounts were empty and were likely to remain so for the near future. Had they

\footnotetext{
${ }^{28}$ The Saratov enterprise that succeeded in collecting via ispolnitel'nyy list got the full amount of its judgment, which explains why the mean for the sample of four is 25 percent.
} 
presented the court orders to the banks, they would have automatically been the beneficiaries of any funds that came into the accounts over the next six months.

As I probed into what originally motivated the creditors to initiate litigation, I found that Saratov was markedly different from Moscow and Yekaterinburg. The Saratov sample had an unusually high concentration of enterprises that were prompted to file suit as a result of accounting or tax concerns (Hendley, forthcoming). About two-thirds of the Saratov sample indicated that they were motivated by accounting or that tax concerns contributed to their decision to litigate. By contrast, only about a quarter of the Moscow and Yekaterinburg enterprises were prompted to sue by accounting concerns. ${ }^{29}$ The subsequent behavior of the Saratov enterprises was colored by these concerns. Of the 19 Saratov enterprises that admitted to being motivated by accounting concerns-all of which got ispolnitel'nyye listy — only one made the effort to collect by presenting the ispolnitel'nyy list to the debtor-defendant's bank. This intrepid creditor had the good fortune to recover the full amount of the judgment in this way. The remaining Saratov creditors did nothing and got nothing. Their failure to take the minimal step of presenting their ispolnitel'nyye listy to the banks strongly suggests that these Saratov enterprises never expected to recover the money owed to them and that, instead, their intention was to create a record that would convince state officials (and other third parties) of the genuineness of the underlying debts. ${ }^{30}$ Moscow and Yekaterinburg creditors seem less calculating. Enterprises in these regions that were troubled about accounting issues were more likely to take their ispolnitel'nyye listy to the bank than those that had no such concerns, indicating that, for them, the litigation had no hidden agenda and was simply a way to collect on overdue debt. ${ }^{31}$

Given this patent disdain for the potential of ispolnitel'nyye listy on the part of Saratov managers, what explains their amenability to using them in the future? Indeed this attitude was mirrored by enterprise managers in all three regions who sat on their ispolnitel'nyye listy as well as by those who got nothing even after presenting their court orders to the debtors' banks. It seems illogical. Why would managers who gained nothing from this strategy convey enthusiasm for it? Perhaps their attitude stems from the much-vaunted sense of fatalism among Russians. In other words, rather than ask "why," the better question is "why not." There are, after all, no hidden costs associated with ispolnitel'nyye listy, either tangible or

\footnotetext{
${ }^{29}$ The situation is even more uneven with regard to tax concerns. Again, about two-thirds of the Saratov enterprises indicated that tax-related worries had inspired them to file the lawsuit, whereas this concern motivated only 13 percent of the Moscow and Yekaterinburg enterprises in my sample.

${ }^{30}$ The data reveal a similar pattern for Saratov enterprises motivated by tax concerns (which were mostly the same enterprises that had confessed to accounting worries).

${ }^{31}$ The data reveal a similar pattern for the Moscow and Yekaterinburg enterprises motivated by tax concerns.
} 
relational. A manager might reason that there is no down side to getting the court order, but might act on it only if he had reason to believe there were funds in the account. The regional variation in use may reflect a change in these assumptions in Moscow that has not yet made its way to Saratov or Yekaterinburg.

A more telling measure of what managers really thought of this strategy is their response to the question about its effectiveness (last column of Table 8). The low score from the Saratov sample is entirely understandable. For three of the four who tried to use ispolnitel'nyye listy, it was a complete failure. Likewise the relatively high scores from the Moscow and Yekaterinburg samples make sense. A majority of these enterprises succeeded in collecting through this method. Their generally positive attitude toward the strategy is understandable.

\section{Bailiffs}

Creditors frustrated by the failure of debtor-defendants to pay judgments of the arbitrazh courts can seek help from bailiffs (sudebnyye pristavy). The sudebnyye pristavy are the state-sanctioned institution charged with enforcing judicial decisions. As I noted above, it underwent a wholesale overhaul in the late 1990s that left the bailiffs with increased powers and, hopefully, prestige. Though the reforms represent an improvement, dissatisfactions persist. The national newspaper, Trud, estimates that one-third of the letters to the editors it receives complain about problems with enforcing judgments related to bailiffs (Golubyov in Trud, November 25, 2002). The assistance of the sudebnyy pristav is not provided automatically; creditors must seek them out. Thus, unlike the ispolnitel'nyye listy, which are automatically issued at the conclusion of all cases, initiating an action by the sudebnyye pristavy requires overt effort on the part of creditors. Whether to ask for such help is solely within the discretion of the creditor. It is, of course, only one of several routes open to creditors. They might prefer to rely on other enterprises or on business associations to pressure the delinquent customer to pay the outstanding judgment. Some creditors may turn to private enforcement services that trade in threats of what might happen if payment is not forthcoming and perhaps even follow through on these threats. Creditors may use more than one of these options, either sequentially or concurrently.

Within my sample, most creditors that had failed to collect fully through ispolnitel'nyye listy or by voluntary payments made use of the bailiffs. When the enterprises that had gotten the full amount of their judgment through these methods (16) and those that refused to respond to follow-up questions (8) are removed, it turns out that a remarkable 67 percent of those remaining sought help from the sudebnyye pristavy (51 of 76). There is also a strong correlation between getting a court order and appealing to the bailiffs, suggesting that these enterprises were comfortable with legalistic remedies. Among the group of enterprises that got ispolnitel'nyye listy but were unable to recover their judgment (whether due 
to their own failure to present the court order to the bank or the evasive behavior of the debtor-defendant), almost three-fourths took the next step and asked the bailiffs for help. ${ }^{32}$ Nor was this the first interaction with the bailiffs for most of them. About two-thirds (65.3 percent) reported that they "routinely" sought help from the sudebnyye pristavy. ${ }^{33}$ Perhaps their experience taught them that waiting around to do so was pointless because most of them (59.6 percent) initiated the process within a month of the finalization of the judgment. Reforming the bailiff service seemed to raise its profile among these creditors. For the most part, their use of the sudebnyye pristavy began only after these reforms had been undertaken. ${ }^{34}$

As with the court orders, there is a strong all-or-nothing pattern to the results for those using bailiffs. Though five creditors (9.8 percent) ended up collecting less than half of the judgment, ${ }^{35}$ the remainder was divided between those that got the full amount of the judgment (39.2 percent) and those that got nothing (51 percent). As a whole, the enterprise managers in my sample who made an effort to enforce their judgments via the bailiffs ended up collecting 40 percent of the judgment. This relative lack of success apparently colored their assessments of the effectiveness of sudebnyye pristavy. The scores given are consistently lower than those for court orders.

The data provide some insight into the conditions under which creditors turn to the bailiffs. As I had anticipated, creditors who were collecting debts from first-time customers were the most likely to seek out help from the sudebnyye pristavy. Their lack of prior experience with these customers left them in the dark as to whether payment would be forthcoming without some outside stimulus. Any patience they might have had was extinguished by the time the arbitrazh court judgment was rendered. Along similar lines, I had expected that among long-term trading partners, the propensity to use the bailiffs would be highly correlated with the length of their relationship. It is not. The average length of the relationship between the parties was approximately the same for both those that used bailiffs and those that abstained. ${ }^{36}$

\footnotetext{
${ }^{32}$ Of the three enterprises that presented an ispolnitel'nyy list to the bank but failed to recover anything, only one Moscow enterprise went to the bailiffs. This creditor had gotten 5 percent of the judgment through the ispolnitel'nyy list; the bailiffs were unable to recover any additional amounts.

${ }^{33}$ Among the group of creditors that resorted to bailiffs, it was the first time for only 10.3 percent. On average, they indicated that they had sought help from the bailiffs 20 times during 2000. The creditors in my sample that bypassed the bailiffs were not, as a group, unfamiliar with the bailiff service, though they had less enthusiasm for it. On average, they used it six times during 2000.

${ }^{34}$ This trend was most noticeable in Yekaterinburg and Saratov, where 74 percent and 80 percent, respectively, of the creditors first used the bailiffs in 1998 or after. A comparison to Moscow is complicated by the general unwillingness of the Moscow creditors to respond to this question. Only five creditors answered the question. Of them, three had begun to use the bailiffs in the post-reform era.

${ }^{35}$ The mean amount collected by these five creditors was 27 percent.
} 
The organizational structure and size of the parties seems to matter. Smaller firms (closed joint-stock companies and limited liability companies) emerge as the most active in this realm, both as the initiators of action by the sudebnyye pristavy and as a target of their efforts. As I noted earlier, these firms tend to be less well-established than the large firms (open jointstock companies), most of which had prior lives as state-owned enterprises during the Soviet era. Because these smaller companies are, by definition, newer, their relationships with customers and suppliers typically are more tenuous. ${ }^{37}$ They also tend to be transient, which may inspire creditors to be more aggressive when dealing with them as defendants. Thus, while these small firms were defendants in 38.5 percent of the cases for which using bailiffs was a viable option (excluding those in which the creditors had collected using other methods or had refused to respond to any follow-up questions), they were the defendants in a solid majority (55.8 percent) of the cases where creditors actually used the bailiffs.

On the other hand, the impact of legal representation was less than I had expected. Unlike court orders, which require no special legal knowledge to obtain, the rules governing the bailiffs are fairly complicated. Thus, I had hypothesized that both the use of sudebnyye pristavy and the ultimate recovery would be highly correlated with the availability of legal expertise to creditors. ${ }^{38}$ The data refute this hypothesis. The subset of firms that used the bailiffs was no more likely to have an internal legal department than was the overall sample. Even more telling, the incidence of legal departments among the firms that were successful in collecting through the bailiffs was not any higher than that for the sample as a whole. The patterns do not change when one looks past the availability of legal expertise to its use. Firms that were represented at the hearing were not especially likely to call on the bailiffs, nor did they enjoy any distinctive pattern of success in these efforts. Likewise, the use of lawyers by debtor-defendants had little

\footnotetext{
${ }^{36}$ The mean for enterprises with preexisting relationships that used the sudebnyye pristavy was 4.3 years, whereas the mean for those who did not was 4.4 years.

${ }^{37}$ These forms of ownership were not legalized until the late 1980s and did not become widely popular until the 1990s (Maggs, 1992). Some closed joint-stock companies and limited liability companies were not started from scratch, but were spun off from state-owned enterprises. These spin-offs often were able to capitalize on the goodwill of their parent companies and were able to build on the trading partnerships that had been established during the decades of Soviet power. My data do not allow me to segregate such spin-offs from the broader category of closed joint-stock companies and limited liability companies.

${ }^{38}$ Courthouse rumors suggest that the heavy caseload carried by bailiffs results in the squeaky wheel getting greased, e.g., creditors that pester them and/or volunteer to assist them in carrying out their duties are more likely to recover. According to my conversations with arbitrazh judges and litigants, banks and other frequent litigators sometimes have groups of lawyers that, in effect, operate as shadow bailiffs. Because these lawyers constantly deal with the same sort of debt, they are often more knowledgeable about the specifics of collection than are the sudebnyye pristavy assigned to their cases. Their goal is to facilitate the work of the bailiffs. I found no evidence to substantiate these rumors, but then the relatively small amounts involved in the cases in my database might not have provided sufficient incentive to develop this capability.
} 
impact. Kahn (2002, p. 164) argues that defendants in arbitrazh cases tend to retain lawyers to help them delay or even avoid the judgment. This assumption did not play out in my sample. Among the cases in which the creditors were unsuccessful in collecting anything through the bailiffs, the percentage of defendants who were represented at the hearing was exactly the same as that for the overall sample. There was no cluster of defendants with heightened legal knowledge or skills. How should these results be interpreted? Taken superficially, they would seem to signal the unimportance of legal representation, given that its effect seems to wash out. But such an interpretation would be a mistake. Instead, the key finding is that legal representation in arbitrazh hearings has now become standard and that most firms understand how to mobilize the bailiffs on their behalf, if they so desire.

As with the use of ispolnitel'nyye listy, creditors' use of bailiffs' services as well as their attitudes toward the bailiffs is highly skewed regionally (see Table 9). Once again, Moscow and Saratov present mirror images. Whereas two-thirds of the Moscow enterprises that appealed to the sudebnyye pristavy (12 of 18) saw their judgments fully enforced, the Saratov enterprises were less fortunate. Almost three-fourths (15 of 21) of those that sought the help of the bailiffs were left empty-handed. The Yekaterinburg creditors did not fare much better. Over half (7 of 12) of those that used the bailiffs were stymied in their efforts at collection.

Moscow enterprises emerge as the most avid utilizers of the services of bailiffs and the most sanguine about their effectiveness. Their positive view of the sudebnyye pristavy seems to follow from their high success rate in the cases being investigated. The abject disappointment of Saratov creditors is just as clear from their low assessments of effectiveness. Interestingly, when the query is broadened, the enthusiasm of the Moscow enterprises becomes more muted. As compared with the Yekaterinburg and Saratov samples, far fewer of the Moscow enterprises report using bailiffs "routinely." While three-fourths of the enterprises outside Moscow claim routine use of the sudebnyye pristavy, a bare majority (52.9 percent) of the Moscow creditors put themselves in this category. The responses to the question as to whether they would use the bailiffs in the future reveals a similar, though less pronounced, disparity. Nowhere are creditors downbeat, but those outside Moscow are more eager than their colleagues from the capital. Almost 85 percent of the creditors from Yekaterinburg and Saratov replied that they would "very likely" use the sudebnyye pristavy if an opportunity presented itself in the future, whereas this category represented 66 percent of Moscow creditors. To be sure, this hardly represents a snub of bailiffs' services, but the fervor of creditors from the three regions seems somehow out of whack.

What explains this discordance? More importantly, what explains the dismal record of the Saratov creditors in my sample? One logical explanation emerges from a regional analysis of the data on the length of the relationship between the parties. Saratov creditors with first-time customers turned to the bailiffs with greater frequency than creditors elsewhere. ${ }^{39}$ 


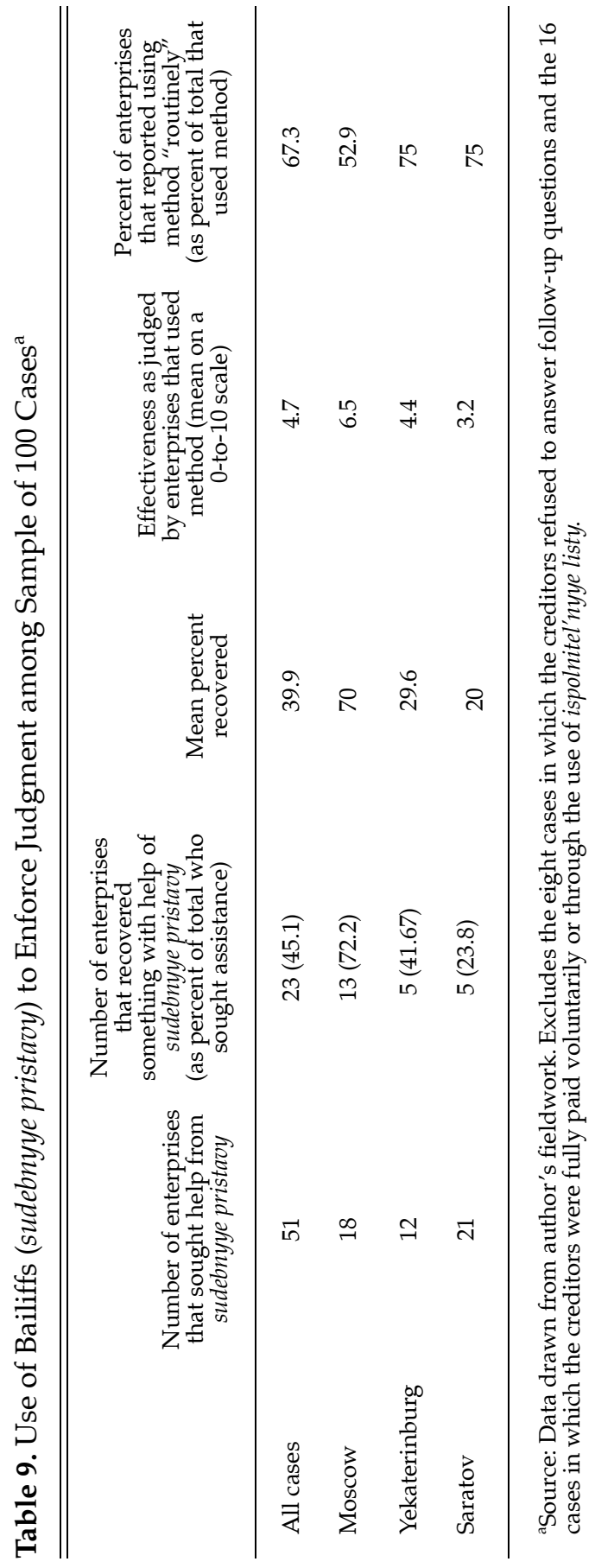


Given the difficulties of assessing the creditworthiness of new customers and the attendant problems associated with collecting from them, the almost uniform lack of success of the Saratov creditors (or, perhaps more accurately, the Saratov bailiffs) seems less anomalous. The mixed motives of Saratov creditors leave some doubt as to whether their primary goal was recovering the amounts owed. Among the enterprises that used sudebnyye pristavy, those from Saratov were more than twice as likely to be motivated by accounting and tax concerns than was the overall sample. But if these Saratov creditors sued only to establish the genuineness of the debt and had no realistic hope of collecting on the judgment, then why did they bother going to the bailiffs? As I have emphasized, this requires an effort on their part. Of the five Saratov creditors that recovered some or all of their judgment with the bailiffs' assistance, three were indifferent to accounting and/or tax concerns and so can be seen as being primarily motivated by recovering the debt. Their appeals to the sudebnyye pristavy make sense. As to the other two, who were driven by the desire to demonstrate that the debt was bona fide, why they took the trouble to ask the bailiffs for help remains a mystery. Perhaps they viewed it as a no-lose option. In other words, even though the chances of recovery were slim, they were marginally better if the bailiffs were involved than if they were not.

\section{CONCLUSIONS}

What does this study reveal about the wisdom of litigating for Russian businessmen? Are they wasting their time? My findings provide no easy answer to this question. At the same time, they suggest that the unqualified pessimism about the enforceability of arbitrazh court judgments that has become standard in the scholarly literature and the popular press is unfounded. Almost two-thirds of my sample (64 percent) came away with some portion of the amount awarded by the court. Admittedly, on average, they recovered less than half of the judgment-not a record to be emulated. But neither is it the total disaster that the Russian media would lead one to expect.

How does the collection record for the arbitrazh courts stack up against analogous courts elsewhere? Comparisons of courts in different legal systems are always treacherous because of discrepancies in institutional structures. In this instance, the task is also complicated by the paucity of empirical work on enforcement. Yet the petty debts that make up my sample allow for a comparison between the arbitrazh courts and small claims courts in the U.S. and England.$^{40}$ Like the arbitrazh courts, small claims courts pride themselves on processing cases quickly and inexpensively, and their dockets are dominated by business-initiated debt collection. ${ }^{41}$ For example, a 1990 study of the Iowa small claims courts revealed

\footnotetext{
${ }^{39}$ In the sample as a whole, about 45 percent of creditors who appealed to the bailiffs were involved with first-time customers. In Saratov, however, this percentage shot up to 65.
} 
business-related disputes made up 62 percent of the docket (Elwell and Carlson, 1990, p. 484). The comparison is, of course, somewhat compromised by the asymmetry in the jurisdiction contours of the two systems. Small claims courts serve individuals as well as businesses, while the Russian courts are limited to hearing disputes brought by or against legal entities. Even so, the comparison provides some insight into whether arbitrazh courts judgments are especially resistant to enforcement. The same Iowa studied showed that, for cases brought by one business against another-the category that is most closely analogous to arbitrazh court cases-almost three-fourths (71 percent) of creditors came away emptyhanded, while 24 percent got the full amount of the judgment and 4 percent got something (Elwell and Carlson, p. 521). ${ }^{42}$ By putting the results of my investigation into the arbitrazh courts into a comparative context, they suddenly seem less dismal.

Several indisputable patterns emerge from my findings. The first is that delinquent customers in Russia do not easily part with their money, even when they have been adjudged liable by the arbitrazh courts. Comparative research establishes that this is not a Russian quirk (e.g., Elwell and Carlson, 1990; Whelan, 1990). According to one group of Denver-based researchers, "[t]he small claims court presents a central irony: winning is easy but collecting is difficult" (Best et al., 1994, p. 345). This sentiment was echoed by John Baldwin, who studied the small claims process in England and Wales:

When interviewed at the end of court hearings, successful plaintiffs frequently expressed relief and satisfaction that the matter had at last been concluded. ... Their assumption was that, since the

\footnotetext{
${ }^{40} \mathrm{~A}$ comparison between Russia and countries that share its civil law heritage might seem more apt. But much of continental Europe has an abbreviated procedure for collecting petty debts that allows creditors to bypass full-fledged hearings unless the debtors involved object (e.g., Blankenburg, 1994; Rohl, 1990). This summary process bears little resemblance to what I found in the arbitrazh courts in 2000, though the new procedural code (which went into effect in September 2002) introduces a similarly streamlined procedure for simple uncontested debt cases (Hendley, 2003).

${ }^{41}$ Whether small claims courts should hear business disputes is much debated in the literature. Yngvesson and Hennessey $(1975$, p. 36) summarize the discussion: "[t]he data indicate that in most courts where business plaintiffs are permitted, these plaintiffs will in fact tend to predominate, and that they will usually be suing individual (non-business) defendants." Indeed, some courts have barred businesses from initiating claims in these courts, though businesses can still be brought into the small claims process as defendants (e.g., Sarat, 1976, p. 344). In his study of the small claims courts in England and Wales, Baldwin found that twothirds of the cases involved small firms either as plaintiff or defendant. He bristles at the criticism that these courts are dominated by business, however, stating that: "[t]he small claims procedure is not, therefore, monopolized, as some writers have argued, by big business or, indeed, by other large and powerful organizations: it is used mainly by small business concerns and by private individuals" (1994, p. 26).

${ }^{42}$ Along similar lines, a 1994 study of the Denver small claims courts found that more than half of all plaintiffs (55 percent) collected no part of their judgments. The remainder collected, on average, only 31 percent of the amounts awarded judgments (Best et al., 1994, p. 365).
} 
district judge had found in their favour, that was an end of the matter. ... It would in fact have been more realistic for plaintiffs to regard the hearing as merely marking the end of round one in what might well prove to be a prolonged, acrimonious, and ultimately fruitless, contest (Baldwin, 1994, p. 128).

Much the same could be said for Russian plaintiffs, except that the unrelenting criticism of enforcement in the popular press probably left them less surprised by the difficulties they encountered in collecting their judgments than the plaintiffs interviewed by Baldwin. But the basic trajectory of their experiences - an uphill battle to get any money-is the same.

Russian debtor-defendants do seem to be more unwilling than debtors elsewhere to pay judgments without being prodded. In 99 of the 100 cases I studied, the creditor prevailed. Yet only six of the debtors that had been found liable paid on their own. Ultimately an additional 58 handed over some or all of the judgment, but only after the funds were garnished through an ispolnitel'nyy list or after they were forcibly collected by a sudebnyy pristav. Standing on its own, this rate of voluntary compliance seems shockingly low. Placing it in a comparative framework does little to cushion the blow. The rates of voluntary compliance in small claims courts in the U.S. and in England and Wales are uniformly higher. A study of the Iowa small claims court found that about 15 percent of losing defendants paid the full amount of their judgments without any prodding from the plaintiffs (or their agents) (Elwell and Carlson, 1990, p. 518). The picture was rosier in England and Wales, though still far from perfect. Much like me, Baldwin contacted the winning plaintiffs in 100 cases six months after their decisions had been rendered, and found that about one-third (31.9 percent) had received payment of their judgments in full and on time (Baldwin, p. 134). ${ }^{43}$ By Russian standards, such results would be cause for jubilation. But Baldwin characterizes them as "disturbing" (Baldwin, p. 133). Imagine his reaction to the 6 percent compliance rate that I found among business debtor-defendants in Russia.

The almost-uniform unwillingness of Russian debtors to pay their judgments without being legally forced to do so is indicative of a deeper problem. Not paying debts became the norm during the 1990s; it was a mechanism of coping with the economic depression and the dramatic loss of liquidity within Russian industry. This non-payments crisis carried over into the courts. Between 1994 and 2000, the number of these debt cases brought to the arbitrazh courts increased by 160 percent. The sad reality behind these lawsuits and the underlying debts was a lack of value in the Russian economy. For the most part, enterprises were surviving through in-kind exchanges; they had no cash to pay for supplies. They were always

\footnotetext{
${ }^{43}$ Neither Elwell and Carlson (1990) nor Baldwin (1994) segregates their results by the type of case. Thus, these percentages reflect not only disputes between businesses, but also claims brought by and against individuals.
} 
robbing from Peter to pay Paul, and eventually this caught up with them and gave rise to lawsuits. Whether the root cause of the unwillingness of debtor-defendants to pay after being held liable was their illiquidity or their lack of respect for the arbitrazh courts is unclear. I suspect that, at least at the outset, the former played a greater role. But over time, as they learned that not paying brought few consequences, any hesitation over defying the courts dissipated. Enterprises that failed to live up to their obligations, whether contractual or court-imposed, were not ostracized. My guess is that, as Russian firms operationalized the lessons learned, the rate of voluntary payments actually decreased over the course of the 1990s, though my data are inadequate to confirm this.

What can be done to combat this epidemic of shirking from arbitrazh court judgments? Recent years have witnessed ambitious efforts to improve the institutions that make up the enforcement system, most notably, the overhauling of the sudebnyye pristavy in the late 1990s. Such reforms certainly have made a difference. Witness the fact that most of the creditors from Yekaterinburg and Saratov that appealed to the sudebnyye pristavy for help did so for the first time only after the process had been revamped. But the institutional reforms to date have been incomplete and insufficient. As Kahn (2002, p. 165) documents, the fee structure provides little incentive for bailiffs to pursue large arbitrazh court judgments. Doing so often takes considerable time because of the difficulty of finding and disposing of the debtor-defendant's property. The bailiff service collects 7 percent of the judgment as its fee, and of that, the bailiff involved is allowed to retain 2 percent of the judgment for his or her efforts. On the surface this would seem to be a powerful inducement to go after large debts. But it is undermined by the 800 ruble (about $\$ 27$ ) cap placed on the amount that can be awarded to a bailiff in any case. As a practical matter, this means that a bailiff gets the same financial reward for all cases of 40,000 rubles or more (approximately $\$ 1,333$ ). The potential impact on their commitment to arbitrazh cases is obvious. As Kahn (2002, pp. 173-179) notes, this opens the door to corruption. Precisely how the sudebnyye pristavy ought to be reformed in order that they better serve the interests of litigants in the arbitrazh courts is beyond the scope of this article.

But even if a creditor has the good fortune to encounter a wellintentioned and energetic bailiff, this bailiff cannot recover anything if the debtor is operating in a cash-free environment with equipment that is on its last legs. Thus, the availability of funds-or, in the Russian case, the unavailability of funds-poses a practical obstacle to recovery for many creditors. Improving the efficiency of the bailiffs does nothing to change the mindset of Russian businessmen about the importance of living up to their contractual obligations. Such a change is absolutely essential to making the enforcement system work better, but is not something that the state can dictate from on high. Attitudes about contractual behavior reflect the broader business culture. So long as business scoundrels are lionized in Russia, the behavior of ordinary businessmen is unlikely to change. 
The second pattern that emerges inescapably from my data is the regional disparity in the ability of creditors to enforce arbitrazh court judgments (see Tables 6, 8, and 9). Indeed, whether litigating makes sense may depend on where the business is located. Most Moscow firms got something for their efforts, whereas most Saratov firms did not. Moscow firms are, therefore, justified in approaching the arbitrazh courts with an expectation of being able to collect on their judgments. After all, almost two-thirds (65.6 percent) of the Moscow creditors in my sample ended up with the full amount of the judgment. Yet the money did not fall into their laps. Only two debtor-defendants from Moscow paid voluntarily. The remainder of the creditors had to pester their customers. Having the judgment in hand made a difference. Once their decisions became final, the creditors were issued ispolnitel'nyye listy that entitled them to any available funds in the debtor-defendants' bank accounts. The process was automatic and inexorable, assuming the accounts in question were not empty. But the creditor had to put the process in motion by taking the ispolnitel'nyy list to the bank. If going to the bank proved fruitless (as it did for seven of the 15 Moscow creditors that tried this strategy), then having the judgment allowed the creditor to ask the bailiffs for help. A number of Moscow creditors who used the bailiffs did not bother approaching the banks, probably because they knew the accounts had been depleted. But again, the onus was on the creditor to activate the bailiffs. Thus, one reason why the Moscow creditors enjoyed greater success than their Yekaterinburg and Saratov counterparts in enforcing their arbitrazh court judgments was that they worked harder at it. But that was only one reason. After all, creditors elsewhere took the initiative and had less to show for it.

The better results for the Moscow creditors can also be attributed to the existence of stronger financial institutions and a shift in the business culture away from tolerating (and rewarding) enterprises that fail to live up to their contractual obligations. Moscow firms were able to recover their judgments via ispolnitel'nyye listy because the accounts of their debtordefendants had funds in them. This suggests that, in Moscow, banks are becoming true banks in the sense that firms are using them to pay for supplies and get payment for their output from customers. Likewise, the strong track record of Moscow firms that worked through the bailiffs seems to reflect of the better economic conditions prevailing in the capital. Bailiffs can only enforce judgments when the debtor-defendants have something of value to seize, whether it is cash or property.

The Saratov firms were patently less successful than the Moscow firms in enforcing judgments. To some extent, they have only themselves to blame. Though most of them got ispolnitel'nyye listy, only a few (four of 26) took them to the banks of their debtor-defendants. Doing so would have required minimal effort because, for the most part, the parties were both from Saratov Oblast'. Thus, the inescapable conclusion is that the Saratov creditors knew that the accounts were empty. It follows that their agenda in bringing the lawsuits may have had less to do with recovering the sums owed and more to do with substantiating the genuineness of the debt. This 
is not to say that the Saratov creditors were uninterested in being repaid. But is that what they expected when they initiated the litigation? If they knew that their customers were effectively judgment-proof, then why pursue legal remedies? Though the costs-both tangible and intangibleassociated with using the arbitrazh courts are remarkably low, litigating is still no fun for either side. The enhanced rights to recovery the creditors gained by securing a court judgment were useless against insolvent defendants. Going to court makes sense only when the deeper motivations of documenting their debts is factored in. The Saratov enterprises may not have gotten much money through litigating, but the decision itself provided something of value to them by definitively establishing the existence of the underlying debts.

The final and, in many ways, most intriguing pattern was the willingness of creditors to return to the arbitrazh courts again and again, notwithstanding the difficulties in enforcing judgments. The creditors in my sample had used the courts repeatedly during 2000 to collect overdue debts and, when asked about their future plans, did not shy away from the possibility of pursuing legal remedies. To some extent, this enthusiasm for litigating is to be expected from my sample. Their very presence in the arbitrazh system conveys an openness to legalistic remedies which is not necessarily shared by the general population of Russian enterprises. But the existence of this core group of regular litigators deserves further exploration, given that it runs counter to the generally accepted view of Russian enterprises as resistant to law and legal remedies. The relatively small size of my sample makes my results suggestive at best. But the findings underscore the need for follow-up research on a larger scale to determine how the process of implementing judicial decisions is actually working in post-Soviet Russia.

\section{REFERENCES}

Arbitrazhnyy protsessual'nyy kodeks Rossiyskoy Federatsii (Arbitrazh Procedural Code of the Russian Federation) [APK], Vestnik Vysshego Arbitrazhnogo Suda Rossiyskoy Federatsii, 6:25-79, 1995.

Baldwin, John, Small Claims in the County Courts in England and Wales: The Bargain Basement of Civil Justice? Oxford: Clarendon Press, 1997.

Berkowitz, Daniel and Wei Li, "Tax Rights in Transition Economies: A Tragedy of the Commons?" Journal of Public Economics, 76, 3:369-397, June 2000.

Best, Arthur and Deborah Zalesne with Kathleen Bridges, Kathryn Chenoweth, Lisa Fine, Jonathan L. Miller, and Kimberly White, "Peace, Wealth, Happiness, and Small Claim Courts: A Case Study," Fordham Urban Law Journal, 21, 2:343-379, Winter 1994.

Blankenburg, Erhard, "The Infrastructure for Avoiding Civil Litigation: Comparing Cultures of Legal Behavior in The Netherlands and West Germany," Law \& Society Review, 28, 4:789-808, November 1994.

Elwell, Suzanne E. and Christopher Carlson, "The Iowa Small Claims Court: An Empirical Analysis," Iowa Law Review, 75, 2:433-538, January 1990. 
Goskomstat, Regiony Rossii: informatsionno-staticheskiy sbornik (Regions of Russia: An information-statistical collection). Moscow: Goskomstat Rossii, 2001.

Goskomstat, Rossiyskiy statisticheskiy yezhegodnik (Russian statistical yearbook). Moscow: Goskomstat Rossii, 2000.

Hendley, Kathryn, "Business Litigation in the Transition: A Portrait of Debt Collection," Law \& Society Review, forthcoming.

Hendley, Kathryn, "Reforming the Procedural Rules for Business Litigation in Russia: To What End?" Demokratizatsiya, 11, 3:363-380, Summer 2003.

Hendley, Kathryn, "Beyond the Tip of the Iceberg: Business Disputes in Russia," in Peter Murrell, ed., Assessing the Value of Law in Transition Economies. Ann Arbor, MI: University of Michigan Press, 2001.

Hendley, Kathryn, "How Russian Enterprises Cope with Payments Problems," PostSoviet Affairs, 15, 3:201-234, July-September 1999.

Hendley, Kathryn, Barry W. Ickes, Peter Murrell, and Randi Ryterman, “Observations on the Use of Law by Russian Enterprises," Post-Soviet Affairs, 13, 1:19-41, April-June 1997.

Hendley, Kathryn, Peter Murrell, and Randi Ryterman, "Law, Relationships, and Private Enforcement: Transactional Strategies of Russian Enterprises," Europe-Asia Studies, 52, 4:627-656, June 2000.

Hendley, Kathryn and Peter Murrell, "Dispute Resolution in Russia: A Regional Perspective," in Harry G. Broadman, ed., Unleashing Russia's Business Potential: Lessons from the Regions for Building Market Institution, World Bank Discussion Paper no. 434, Washington, DC, March 2002.

Johnson, Simon, Daniel Kaufmann, John McMillan, and Christopher Woodruff, "Why Do Firms Hide? Bribes and Unofficial Activity," Journal of Public Economics, 76, 3:495-520, June 2000.

Kahn, Peter L., "The Russian Bailiffs Service and the Enforcement of Civil Judgments," Post-Soviet Affairs, 18, 2:148-181, April-June 2002.

Maggs, Peter B., "Legal Forms of Doing Business in Russia," North Carolina Journal of International Law and Commercial Regulation, 18, 1:173-192, Fall 1992.

Ob ispolnitel'nom proizvodstve ("On Enforcement Proceedings"), Federal Law No. 119FZ, Vestnik Vysshego Arbitrazhnogo Suda Rossiyskoy Federatsii, Special Supplement to 10:15-50, 1997.

O sudebnykh pristavakh ("On Bailiffs"), Federal Law No.118-FZ, Vestnik Vysshego Arbitrazhnogo Suda Rossiyskoy Federatsii, Special Supplement to 10:4-15, 1997.

Radaev, V., "The Role of Violence in Russian Business Relations," Problems of Economic Transition, 41, 12:34-61, April 1999.

Rohl, Klaus F., "Small Claims in Civil Court Proceedings in the Federal Republic of Germany," in Christopher J. Whelan, ed., Small Claims Courts: A Comparative Study. Oxford: Clarendon Press, 1990.

Sarat, Austin, "Alternatives in Dispute Processing: Litigation in a Small Claims Court," Law \& Society Review, 10, 3:39-75, Spring 1976.

"Sudebno-arbitrazhnaya statistika: Osnovnyye pokazateli raboty arbitrazhnykh sudov Rossiyskoy Federatsii v 2000-2001 godakh (Judicial-arbitrazh statistics: Basic indicators of the work the arbitrazh courts of the Russian Federation during 2000-2001)," Vestnik Vysshego Arbitrazhnogo Suda, 4:20-29, 2002.

Tyler, Tom R., "Citizen Discontent with Legal Procedures: A Social Science Perspective on Civil Procedure Reform," American Journal of Comparative Law, 45, 4:871-904, Fall 1997. 
Tyler, Tom R., Why People Obey the Law. New Haven, CT: Yale University Press, 1990. Vasil'yeva, Marina, "Nam nuzhno pravovaya ekonomika (We need a legal economy)," Chelovek i zakon, 6:40-46, 1998.

Vasil'yeva, Marina, "Nel'zya zhit' po zakonam dzhungley (It is impossible by the laws of the jungle)," Chelovek i zakon, 7:54-59, 1996.

Volkov, Vadim, Violent Entrepreneurs: The Use of Force in the Making of Russian Capitalism. Ithaca, NY: Cornell University Press, 2002.

Weller, Steven, John C. Ruhnka, and John A. Martin, "American Small Claims Courts," in Christopher J. Whelan, ed., Small Claims Courts: A Comparative Study. Oxford: Clarendon Press, 1990.

Whelan, Christopher J., ed., Small Claims Courts: A Comparative Study. Oxford: Clarendon Press, 1990.

Yakovlev, V.F. and M. K. Yukov, Kommentarii k Arbitrazhnomu protsessual'nomu kodeksu Rossiyskoy Federatsii (Commentary to the Arbitrazh Procedural Code of the Russian Federation). Second edition. Moscow: INFRA-M, 1999.

Yngvesson, Barbara and Patricia Hennessey, "Small Claims, Complex Disputes: A Review of the Small Claims Literature," Law and Society Review, 9, 2:219-74, Winter 1975. 